\title{
SAPHO syndrome associated with acne fulminans in an adolescent patient
}

\author{
Adölesan hastada akne fulminansın eșlik ettiği SAPHO sendromu
}

๑ Sema Aytekin, ๑ Fatih Göktay, ๑ Șirin Yașar, ๑ Duygu Geler Külcü*

Istanbul Haydarpașa Numune Training and Research Hospital, Clinic of Dermatology; ${ }^{*}$ Clinic of Physical Medicine and Rehabilitation, İstanbul, Turkey

Keywords: SAPHO, acne fulminans, isotretinoin, etanercept

Anahtar Kelimeler: SAPHO, akne fulminans, isotretinoin, etanersept

\section{To The Editor,}

Synovitis, acne, pustulosis, hyperostosis, osteitis (SAPHO) syndrome, is a relatively rare disorder ${ }^{1,2}$. We report an adolescence patient with refractory SAPHO syndrome and acne fulminans, successfully treated with isotretinoin and etanercept.

A 17-years-old man admitted with the complaints of fever, severe ulcerative acneiform lesions and inability to walk due to hip pain for the last 10 days while undergoing isotretinoin treatment for acne conglobata. There was severe acne conglabata history for about 3 months. Skin ulcerations and hip pain have developed at the $15^{\text {th }}$ day of the $30 \mathrm{mg} /$ day oral isotretinoin treatment. His family history was unremarkable for acne conglobata or joint disease. Dermatological examination revealed numerous inflammatory nodules, comedones, in addition to painful ulcers with overhanging borders surrounding exudative necrotic plaques on back, chest, gluteal and inguinal areas (Figure $1 \mathrm{a}, \mathrm{b}$ ). The informed consent form was obtained for photographs. On physical examination, bilaterally hip joint movements and lumbar flexion were painful and limited.

Laboratory evaluations demonstrated increased level of C-reactive protein $(7.5 \mathrm{ng} / \mathrm{mL})$, and leukocytosis (26.5 $\mathrm{Ku} / \mathrm{L})$. Blood and urine cultures showed no bacterial growth. Serum immunoglobulin levels were within normal ranges, and rapid plasma reagin test, human leukocyte antigen B27, rheumatoid factor, and anti-nuclear antibody were all negative. His left sternoclavicular and sternocostal joints were painful with palpation. Sacroiliac compression and distraction tests were positive. Bilateral shoulder and hip joints were not limited but painful. His sacroiliac magnetic resonance imaging showed bilateral sacroiliitis (Figure $2 a, b$ ). The whole body bone scintigraphy showed intense uptake at bilateral sacroiliac and sternoclavicular joints revealing bilateral sacroiliitis and sternoclavicular joint arthritis. Initially he was treated with non-steroid anti-inflammatory drugs (NSAIDs), ampicillin/sulbactam and clindamycin for 2 weeks. The symptoms did not resolve by the cessation of isotretinoin and symptomatic treatment. He was treated with 40 mg/day methylprednisolone tapered 6 weeks. While reducing steroid

Address for Correspondence / Yazışma Adresi: Sema Aytekin MD, İstanbul Haydarpaşa Numune Training and Research Hospital, Clinic of Dermatolog, İstanbul, Turkey Phone: +90 5332134959 E-mail: semaaytekin@yahoo.com Received/Geliş Tarihi: 13.08.2018 Accepted/Kabul Tarihi: 09.10.2018 ORCID ID: orcid.org/0000-0003-1376-1573

(c) Telif Hakkı 2019 Deri ve Zührevi Hastalılar Derneği

Türkderm-Deri Hastalıkları ve Frengi Arșivi Dergisi, Galenos Yayınevi tarafından basılmıștır. 


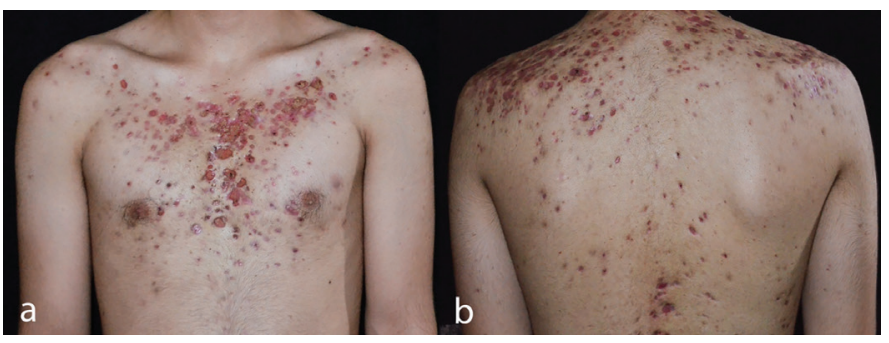

Figure 1 a,b. Comedones and painful ulcers over the chest and back

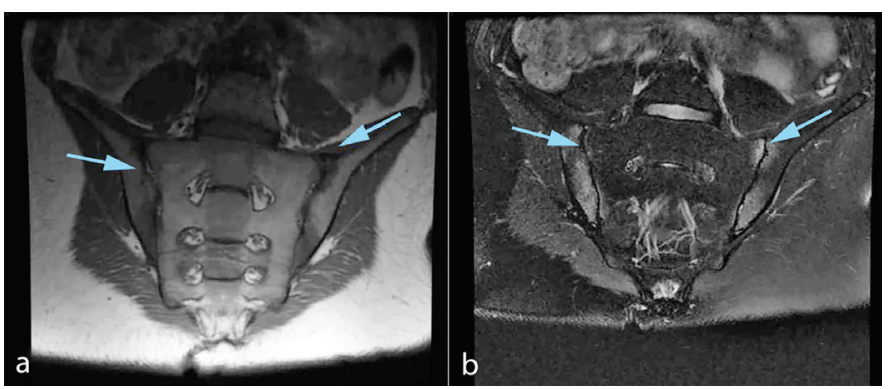

Figure 2. Coronal T1-weighted (a) and STIR-weighted (b) sacroiliac joint magnetic resonance imaging showing inflammation and bone marrow edema on both sides

STIR: Short tau inversion recovery

doses, dapsone $100 \mathrm{mg} /$ day was added, but dapsone hypersensitivity reaction occurred. Then, the joint symptoms of the patient did not improve by the treatment of $15 \mathrm{mg} /$ week methotrexate treatment. Therefore, etanercept was started at a dose of $50 \mathrm{mg} /$ week. Despite the improvement of his joint symptoms, the skin lesions flared. For this reason $0.5 \mathrm{mg} / \mathrm{kg}$ isotretinoin was started. Topical clindamycin and benzoyl peroxide combination was added to treatment. There was marked improvement of his skin lesions in the $6^{\text {th }}$ week of follow-up. At the $9^{\text {th }}$ month of treatment, patient's joint complaints were completely, skin lesions markedly improved.

Palmoplantar pustulosis, severe acne including acne conglabata, acne fulminans or hidradenitis suppurativa, pyoderma gangrenosum, Sweet syndrome are the characteristic cutaneous lesions of SAPHO syndrome. Skin lesions may occur before, after or simultaneously with articular involvements ${ }^{2}$. In our patient articular symptoms and acne conglobata complicated with acne fulminans began after isotretinoin treatment. Although isotretinoin is used for the treatment of SAPHO syndrome, it may also trigger the disease. The use of low dose isotretinoin with systemic steroid was recommended in acne conglabata, because disease may progress acne fulminans ${ }^{3}$.

NSAIDs, corticosteroids, methotrexate, anti-tumour necrosis factoralpha (TNF- $\alpha$ ), bisphosphonates have been reported in the symptomatic treatment of SAPHO syndrome with varying degrees of success. AntiTNF- $\alpha$ agents may be therapeutic options for SAPHO cases unresponsive or refractory to conventional drugs $s^{4,5}$. The combined use of isotretinoin and etanercept in our patient has been very effective.

\section{Ethics}

Informed Consent: The informed consent form was obtained for photographs.

Peer-review: Externally peer-reviewed.

\section{Authorship Contributions}

Surgical and Medical Practices: S.A., Concept: S.A., Design: S.A., F.G., Data Collection or Processing: S.A., Ş.Y., Analysis or Interpretation: S.A., F.G., D.G.K., Literature Search: S.A., Writing: S.A., F.G.

Conflict of Interest: No conflict of interest was declared by the authors.

Financial Disclosure: The authors declared that this study has received no financial support.

\section{References}

1. Divya $B L$, Rao PN. SAPHO syndrome with acne fulminans and severe polyosteitis involving axial skeleton. Indian Dermatol Online J 2016;7:414-7.

2. Zimmermann P, Curtis N. Synovitis, acne, pustulosis, hyperostosis, and osteitis (SAPHO) syndrome - A challenging diagnosis not to be missed. J Infect 2016;72:106-14.

3. Karatas Togral A, Yıldızgoren MT, Koryurek OM, Ekiz T. Can isotretinoin induce articular symptoms in SAPHO syndrome? West Indian Med I 2015;64:167-8.

4. Iqbal M, Kolodney MS. Acne fulminans with synovitis-acne-pustulosishyperostosis-osteitis (SAPHO) syndrome treated with infliximab. J Am Acad Dermatol 2005;52(Suppl 1):118-20.

5. Su YS, Chang $\mathrm{CH}$. SAPHO syndrome associated with acne conglobata successfully treated with etanercept. J Formos Med Assoc 2015;114:562-4. 